\title{
Panicle Nitrogen Strategies for Nitrogen-Efficient Rice Varieties at a Moderate Nitrogen Application Rate in the Lower Reaches of the Yangtze River, China
}

\author{
Chengxin Ju $\mathbb{B}$, Tao Liu and Chengming Sun * (1)
}

Jiangsu Key Laboratory of Crop Genetics and Physiology/Jiangsu Co-Innovation Center for Modern Production Technology of Grain Crops, Agricultural College, Yangzhou University, No.48 Wenhui East Road, Yangzhou 225009, China; cxju@yzu.edu.cn (C.J.); tliu@yzu.edu.cn (T.L.)

* Correspondence: cmsun@yzu.edu.cn; Tel.: +86-514-8797-9381

Citation: Ju, C.; Liu, T.; Sun, C. Panicle Nitrogen Strategies for Nitrogen-Efficient Rice Varieties at a Moderate Nitrogen Application Rate in the Lower Reaches of the Yangtze River, China. Agronomy 2021, 11, 192. https://doi.org/10.3390/agronomy 11020192

Received: 25 December 2020

Accepted: 19 January 2021

Published: 20 January 2021

Publisher's Note: MDPI stays neutral with regard to jurisdictional claims in published maps and institutional affiliations.

Copyright: (c) 2021 by the authors. Licensee MDPI, Basel, Switzerland. This article is an open access article distributed under the terms and conditions of the Creative Commons Attribution (CC BY) license (https:// creativecommons.org/licenses/by/ $4.0 /)$.
Abstract: Nitrogen (N) management is of great importance in rice production, but most previous studies have focused on high $\mathrm{N}$ rates and there is a lack of research on management plans under a moderate $\mathrm{N}$ rate. This study aimed to explore the agronomic and physiological traits of $\mathrm{N}$-efficient rice varieties (NEVs) and to optimize the management strategy at an $\mathrm{N}$ rate below the inflection point of the parabolic curve between $\mathrm{N}$ rate and grain yield. Two NEVs and two $\mathrm{N}$-inefficient rice varieties (NIVs) were planted, and three treatments were designed according to the panicle $\mathrm{N}$ application method. A larger amount of $\mathrm{N}$ applied at panicle initiation (PI) led to higher rice yield and $\mathrm{N}$-use efficiency (NUE). This was mainly due to increases in the total number of spikelets per unit area, root oxidation activity, leaf area duration, and leaf photosynthesis rate as well as to the increased carbon (C) and N utilization rates. Compared with NIVs, NEVs exhibited improved root and shoot functions and higher $\mathrm{C}$ and $\mathrm{N}$ transport characteristics at the moderate $\mathrm{N}$ rate. We suggest that increasing the application of N at PI and that planting of NEVs are important ways to increase rice yield and NUE when adopting moderate $\mathrm{N}$ rates.

Keywords: rice (Oryza sativa L.); $\mathrm{N}$-efficient varieties; $\mathrm{N}$-use efficiency; panicle fertilizer; $\mathrm{N}$ management

\section{Introduction}

China is the world's largest producer and consumer of $\mathrm{N}$ fertilizer [1,2]. For a long time, increasing $\mathrm{N}$ application rate has been one of the most effective measures to increase the yield of rice (Oryza sativa L.) [3,4]. Since 2000, rice yields have increased slowly, with an average annual growth rate of less than $0.5 \%$ (Figure $1 \mathrm{a}$ ). However, the $\mathrm{N}$ rates in China and Jiangsu province are $75 \%$ and $200 \%$ higher than the world average, respectively $[5,6]$. According to statistics from the National Bureau of Statistics (NBS) of China, the N inputs in China and Jiangsu province have been gradually reduced since 2014 and 2009, respectively (Figure 1b). Over the past 10 years, the N input in Jiangsu province has decreased by 20\%, but the rice planting area has stabilized at 2.21 to 2.26 million hectares [7], meaning that the amount of $\mathrm{N}$ applied per unit area has decreased. The relationship between grain yields and $\mathrm{N}$ rate can be described by parabolic equations: in general, the grain yields reached maximums when the $\mathrm{N}$ rate reached the inflection point $[8,9]$. Thus the level of $\mathrm{N}$ application in many paddy fields has decreased below the optimal $\mathrm{N}$ rate. To stabilize and improve rice production at moderate $\mathrm{N}$ levels, $\mathrm{N}$-fertilizer strategies must be improved by growing rice varieties with increase grain yields and $\mathrm{N}$-use efficiency (NUE). This will aid in mitigating environmental costs while meeting the food demand of a growing population [10].

$\mathrm{N}$ is quantitatively the most important mineral nutrient for plant growth and development [11]. In China, the use of $\mathrm{N}$ fertilizer is generally inefficient and causes serious damage to the environment, resulting in significant amounts of greenhouse gas emissions [10]. A 
high level of $\mathrm{N}$ fertilization can drive soil acidification and degrade soil quality [12]. Overuse of $\mathrm{N}$ fertilizers contributes substantially to regional water pollution [10-12]. The selection of N-efficient rice varieties (NEVs) has been known as a promising strategy to maximize grain yield and NUE in crop production and as an essential approach for sustainable agriculture $[13,14]$. Studies have found that high-yielding rice varieties can achieve a relatively high yield under sufficient $\mathrm{N}$ supply [15]. However, some varieties are highly dependent on the input of $\mathrm{N}$ fertilizer and their yield shows a large decrease after the $\mathrm{N}$ rate is reduced; therefore, these varieties are known as $\mathrm{N}$-inefficient varieties (NIVs). In contrast, some varieties have a relatively high yield under a low $\mathrm{N}$ rate and they are known as NEVs $[15,16]$. The main varieties used in rice production in Jiangsu province are mostly NEVs, indicating that some NIVs relying on high $\mathrm{N}$ input have been gradually eliminated under the constantly decreased $\mathrm{N}$ application level [17]. Many NEVs possess a high tillering ability and belong to the multi-spike type [17], especially in the case of mechanical transplanting [18]. Peng et al. found that green super rice (GSR) also had the same plant type [19].
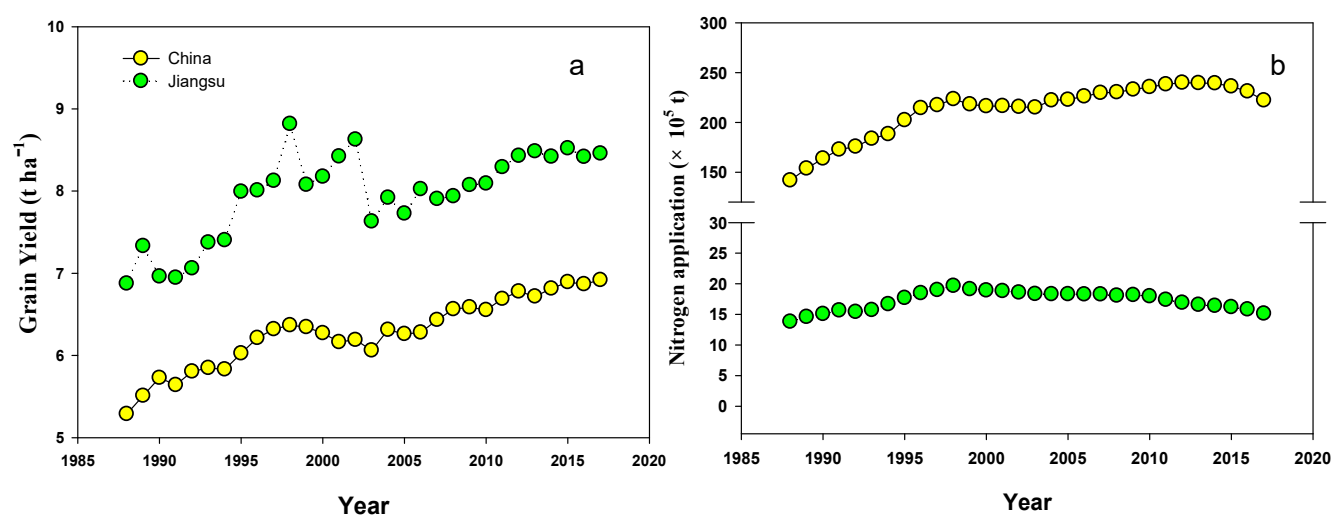

Figure 1. The average grain yield of rice (a) and total agricultural $\mathrm{N}$ application (b) of China and Jiangsu province in the past 30 years (data from the National Bureau of Statistics of China).

Studies have shown that it is most effective to apply $\mathrm{N}$ fertilizer at panicle initiation (PI) for multi-spike varieties [18]. However, it remains unknown whether increasing the proportion of $\mathrm{N}$ fertilizer applied at PI can alleviate the impact of reduced $\mathrm{N}$ application on rice yield after reducing the amount of applied $\mathrm{N}$ fertilizer. Therefore, we designed three $\mathrm{N}$ treatments based on the amount of $\mathrm{N}$ fertilizer applied at PI to study the effects of different amounts of N fertilizer applied at PI on NEV yield and NUE with reduced N application. It would be very meaningful to understand the agronomic and physiological characteristics of NEVs under these different $\mathrm{N}$ managements. The purpose was to investigate rice yield and NUE of NEVs under different treatments and to understand their agronomic and physiological bases by determining root biomass and length, root oxidation activity (ROA), leaf area index (LAI), leaf area duration (LAD), photosynthetic rate of leaves, nonstructural carbohydrate (NSC) accumulation in the stems and N accumulation in the stems and leaves, and its remobilization during grain filling. The results of this study should reveal the high-yield and high-efficiency source and sink mechanism of rice and to provide a reference for NEV breeding.

\section{Materials and Methods}

\subsection{Plant Materials and Growth Conditions}

Field experiments were conducted during the rice growing seasons of 2017 and 2018 at a research farm located in Yizheng Country, Jiangsu Province $\left(32^{\circ} 50^{\prime} \mathrm{N}, 119^{\circ} 23^{\prime} \mathrm{E}\right)$, which was an alluvial plain that is one of the major rice production regions in China. The soil properties of the field were as follows: organic mater of $23.5 \mathrm{~g} \mathrm{~kg}^{-1}$, total $\mathrm{N}$ of $1.08 \mathrm{~g} \mathrm{~kg}^{-1}$, Olsen $\mathrm{P}$ of $31.7 \mathrm{mg} \mathrm{kg}^{-1}$, exchangeable $\mathrm{K}$ of $74.4 \mathrm{mg} \mathrm{kg}^{-1}$ at 0 to $20 \mathrm{~cm}$ soil 
depth, $0.188 \mathrm{~g} \mathrm{~g}^{-1}$ of soil moisture content, and $1.32 \mathrm{~g} \mathrm{~cm}^{-3}$ of soil bulk density. The meteorological data during the rice-growing season across the study years were collected at a weather station close to the field site, shown in Figure 2.
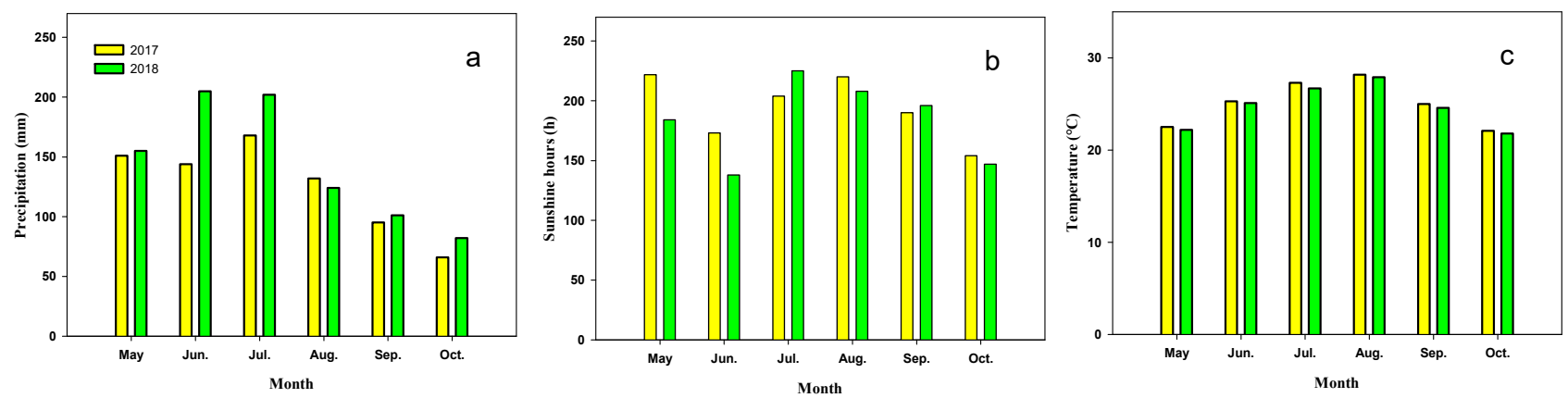

Figure 2. Precipitation (a), sunshine hours (b), and temperature (c) during the growing season of rice in 2017 and 2018 at the field site of Yangzhou, China.

Two N-efficient varieties, Huaidao5 (HD-5) and Lianjing7 (LJ-7), and two N-inefficient varieties, Zhongdao1 (ZD-1) and Yangjing4038 (YJ-4), were grown in the paddy field. The equations between the $\mathrm{N}$ rate and yield, inflection point, and max yield of tested varieties under a N split proportion of 4:2:2:2 are shown in Table 1 . The tested varieties have a similar growth period, ranging from 152 to 155 days from sowing to maturity. The seeds of ZD-1 and LJ-7 were provided by Lianyungang Agricultural Research Institute (Lianyungang, China); the other two rice varieties were obtained from Lixiahe Agricultural Research Institute (Yangzhou, China). The classification of spike type was generally according to the number of spikelets: small-spike type or multi-spike type with less than 140, large-spike type with more than 200, and medium-spike type with 140-200 spikelets per panicle. With the increasing $\mathrm{N}$ rate, the spikelets per panicle improved. The spikelet number of the tested varieties in this study were mostly less than 140 , so they could be considered multi-spike types. The seedlings were raised on 22 May of 2017 and 20 May of 2018 and transplanted on 12 June of 2017 and 10 June of 2018 at a transplanting spacing of $0.33 \mathrm{~m} \times 0.12 \mathrm{~m}$, with three seedlings per hill, by using a rice transplanter. Phosphorus was applied as a single superphosphate at a rate of $40 \mathrm{~kg} \mathrm{ha}^{-1}$, and potassium was applied as $\mathrm{KCl}$ at a rate of $50 \mathrm{~kg} \mathrm{ha}^{-1}$ before transplanting. To avoid yield loss, water, weeds, diseases, and insects were intensively controlled. The heading date and harvest date of the tested varieties were 23-25 August and 16-18 October, respectively.

Table 1. Equations between $\mathrm{N}$ rate and yield, inflection point, and max yield of the tested varieties.

\begin{tabular}{|c|c|c|c|c|}
\hline Variety $^{1}$ & $\begin{array}{c}\text { Equations between } N \text { Rate and } \\
\text { Yield }\end{array}$ & $\mathbf{R}^{2}$ & $\begin{array}{l}\text { Inflection Point } \\
\left(\mathrm{kg} \mathrm{hm}^{-2}\right)\end{array}$ & $\begin{array}{l}\text { Max Yield } \\
\left(\mathrm{kg} \mathrm{hm}^{-2}\right)\end{array}$ \\
\hline HD-5 & $y=-0.0550 x^{2}+28.69 x+6356$ & 0.934 & 260.8 & 10,097 \\
\hline LJ-7 & $y=-0.0535 x^{2}+28.58 x+6519$ & 0.927 & 267.1 & 10,336 \\
\hline ZD-1 & $y=-0.0418 x^{2}+27.33 x+5859$ & 0.939 & 327.3 & 10,326 \\
\hline YJ-4 & $y=-0.0443 x^{2}+28.11 x+5729$ & 0.955 & 308.5 & 10,185 \\
\hline
\end{tabular}

${ }^{1}$ HD-5, Huaidao 5; LJ-7, Lianjing 7; ZD-1, Zhongdao 1; and YJ-4, Yangjing 4038.

\subsection{Treatments}

The experiments were laid out in a split-plot design with $\mathrm{N}$ management as the main plots and varieties as the subplots with three replicates. The plot size was $72 \mathrm{~m}^{-2}$ $(12 \mathrm{~m} \times 6 \mathrm{~m})$, and plots were separated by 1-m-wide ridges. In the high-yield area of lower reaches of the Yangtze River, the average $\mathrm{N}$ input was $300 \mathrm{~kg}$ per hectare, which is $67 \%$ higher than $\mathrm{N}$ application in the single rice cropping system in China. There was no standard criteria to classify high, moderate, and low $\mathrm{N}$ rates. An application rate of 
$200 \mathrm{~kg} \mathrm{hm}^{-2}$ was considered a relatively moderate level in the lower reaches of the Yangtze River, China. Treatments consisted of four $\mathrm{N}$ managements; for each treatment, $\mathrm{N}$ as urea was split into four applications at four growth stages (Table 2).

Table 2. The amount of $\mathrm{N}$ applied to four treatments at different growth stages in the experiment.

\begin{tabular}{|c|c|c|c|c|c|}
\hline \multirow{2}{*}{ N Split } & \multirow{2}{*}{ Growth Stage $^{1}$} & \multicolumn{4}{|c|}{ N Rate $\left(\mathbf{k g ~ h m}^{-2}\right)$} \\
\hline & & No $^{2}$ & N1 & $\mathbf{N} 2$ & N3 \\
\hline 1st application & Pre-transplanting & - & 80 & 80 & 80 \\
\hline 2nd application & Mid tillering (V9) & - & 40 & 40 & 40 \\
\hline 3rd application & Panicle initiation (R0) & - & 0 & 40 & 80 \\
\hline 4th application & Spikelet differentiation (R2) & - & 80 & 40 & 0 \\
\hline Total nitrogen & & 0 & 200 & 200 & 200 \\
\hline
\end{tabular}

${ }^{1}$ The classification of growth stages was according to the methods described by Counce et al. [20]. ${ }^{2}$ N0, zero-N control; N1, panicle N applied at spikelet differentiation (SD); N2, panicle N split at PI and SD; and N3, panicle N applied at panicle initiation (PI).

\subsection{Sampling and Measurements}

Root biomass and root length were determined at about 40, 75, and 125 days after transplanting of growth, shown as the stages of panicle initiation (PI), heading time (HT), and maturity (MA), respectively. Plant samples were separated into four parts: roots, leaves, stems, and panicles (at HT and MA). The dry matter of each part was recorded after drying at $75{ }^{\circ} \mathrm{C}$ to constant weight and weighed. The root length was measured with a scanner (Epson Expression 1680, SeikoEpson, Suwa City, Japan) and analyzed using a root analyzer system developed by regent instruments incorporation, Canada.

The root oxidation activity (ROA) and leaf photosynthetic rate were measured at the same time. The ROA was determined according to the method of Chu et al. [21]. The photosynthetic rate of fully expanded leaves was measured by a portable photosynthetic instrument (Li-Cor 6400, LI-COR, Lincoln, NE, USA). The leaves were measured during 09:00-11:00 $\mathrm{h}$ when photosynthetic active radiation above the canopy was $1300-1500 \mu \mathrm{mol} \mathrm{m}^{-2} \mathrm{~s}^{-1}$ and the parameter of $\mathrm{CO}_{2}$ level of leaf chamber and temperature were $380 \mu \mathrm{mol} \mathrm{mol}^{-1}$ and $28-30{ }^{\circ} \mathrm{C}$, respectively. Each gas exchange analyzer was used in one treatment replicate, and eight leaves were measured for each treatment.

The leaf area index (LAI) was measured at PI, HT, and MA. Six plants (per hill was considered as per plant) were sampled from each treatment for each measurement. Leaf area was determined by scanning the projected area and measured with an area meter (LI-3000 C, LI-COR, Lincoln, NE, USA). The leaf area duration (LAD) was calculated using the following formula:

$$
\mathrm{LAD}=1 / 2(\mathrm{~L} 1+\mathrm{L} 2) \times(\mathrm{t} 2-\mathrm{t} 1)
$$

where L1 and L2 are the previous and next measurements of the leaf area index $\left(\mathrm{m}^{2} \mathrm{~m}^{-2}\right)$, respectively, and $\mathrm{t} 1$ and $\mathrm{t} 2$ present the previous and next times (d), respectively, of the measurement.

$\mathrm{N}$ concentration was determined by microwave disintegration, distillation, and titration to calculate aboveground $\mathrm{N}$ uptake [21]. The methods for calculating NUE indexes were according to Ju et al. [15], including the internal N-use efficiency (IE, the ratio of grain yield to the total $\mathrm{N}$ uptake in plants at maturity), agronomic $\mathrm{N}$-use efficiency (AE, the ratio of yield difference between $\mathrm{N}$ application and no $\mathrm{N}$ application treatment to the amount of $\mathrm{N}$ applied), nitrogen partial factor productivity (PFP, the ratio of grain yield to the amount of $\mathrm{N}$ applied), apparent recovery efficiency (RE, the percentage of fertilizer $\mathrm{N}$ recovered in aboveground plant biomass at the end of the cropping season), and nitrogen physiological efficiency (PE, the ratio of yield difference between $\mathrm{N}$ application and no $\mathrm{N}$ application to the $\mathrm{N}$ uptake difference between $\mathrm{N}$ application and no $\mathrm{N}$ application treatment). The 
amount of nonstructural carbohydrate in the stem was determined at the stages of heading and maturity according to the method described by Yoshida et al. [22].

Plants were harvested manually on 18 October in 2017 and 16 October in 2018. Yield was determined from a harvest area of $6.0 \mathrm{~m}^{2}$ in each plot and adjusted to the standard moisture content of $0.14 \mathrm{~g} \mathrm{H}_{2} \mathrm{O} \mathrm{g}^{-1}$. The aboveground biomass and yield components were determined from plants sampled randomly from each plot. Filled grains were separated by submerging them in salt water (specific gravity $\geq 1.06 \mathrm{~g} \mathrm{~cm}^{-3}$ ).

\subsection{Statistical Analysis}

Statistical data analysis was performed using analysis of variance (SAS Institute, Cary, $\mathrm{NC}$, USA). The statistical model used included sources of variation caused by variety (V), N treatment, and the interaction between $\mathrm{V}$ and $\mathrm{N}$ treatment. Data from each sampling date were analyzed separately. Means were compared by the multiple comparison tests method at the 0.05 probability level. Since root biomass, root length, ROA, and leaf photosynthetic rate exhibited similar patterns at the stages of PI, HT, and MA, data at HT were only presented for conciseness.

\section{Results}

\subsection{Differences in Experimental Factors}

Table 3 shows the computed $\mathrm{F}$ values for the differences in grain yield, yield components, total $\mathrm{N}$ uptake, and agronomic NUE between two study years, the varieties, and the $\mathrm{N}$ treatments. The results showed a significant difference $(p<0.05)$ in plant traits among the varieties, $\mathrm{N}$ treatments, and the interaction between variety and $\mathrm{N}$ treatment (Table 3 ) but no significant difference between years or the interactions year $\times$ variety and year $\times \mathrm{N}$ treatment. Similar results were obtained for other measurements, such as root biomass, LAI, LAD, and remobilized NSC reserve. Since the year was not a significant factor in this study, means of both years were presented.

Table 3. Analysis of variance for grain yield, yield components, total $\mathrm{N}$ uptake, and agronomic $\mathrm{N}$-use efficiency of rice among varieties for $\mathrm{N}$ treatments.

\begin{tabular}{|c|c|c|c|c|c|c|c|}
\hline $\begin{array}{l}\text { Source of } \\
\text { Variation }\end{array}$ & $\mathrm{d} f$ & $\begin{array}{l}\text { Grain } \\
\text { Yield }\end{array}$ & $\begin{array}{l}\text { Spikelets per } \\
\text { Panicle }\end{array}$ & $\begin{array}{c}\text { Filled Grains } \\
\text { Rate }\end{array}$ & $\begin{array}{l}\text { Grain } \\
\text { Weight }\end{array}$ & $\begin{array}{l}\text { Total N } \\
\text { Uptake }\end{array}$ & $\begin{array}{c}\text { Agronomic } \\
\text { NUE }\end{array}$ \\
\hline Year(Y) & 1 & NS & NS & NS & NS & NS & NS \\
\hline Variety(V) & 3 & $* *$ & $* *$ & $* *$ & $* *$ & $* *$ & $* *$ \\
\hline $\mathrm{N}$ treatments $(\mathrm{N})$ & 3 & $* *$ & $* *$ & $* *$ & $* *$ & $* *$ & $* *$ \\
\hline $\mathrm{Y} \times \mathrm{V}$ & 3 & NS & NS & NS & NS & NS & NS \\
\hline $\mathrm{Y} \times \mathrm{N}$ & 3 & NS & NS & NS & NS & NS & NS \\
\hline $\mathrm{V} \times \mathrm{N}$ & 9 & $* *$ & $* *$ & $* *$ & $*$ & $* *$ & $* *$ \\
\hline
\end{tabular}

NS, not significant at the $p=0.05$ level. * Significant at the $p=0.05$ level. ${ }^{* *}$ Significant at the $p=0.01$ level.

\subsection{Grain Yield and NUE}

Under the same $\mathrm{N}$ treatment, the yield difference between the two NEVs or the two NIVs was not significant and the yield of NEVs was significantly higher than that of NIVs. The yield of N3 was significantly higher than those of N1 and N2, mainly because, under $\mathrm{N} 3$, the number of spikelets per panicle increased significantly, although the filled grain percentage and grain weight decreased slightly (Table 4).

Similar to yield (Table 5), NUE indexes of NEVs were significantly higher than those of NIVs under the same $\mathrm{N}$ treatment. With the increasing amount of $\mathrm{N}$ applied at PI from $\mathrm{N} 1$ to N3, the amount of N uptake by plants gradually increased. Compared with N1 and $\mathrm{N} 2$, the N3 treatment increased the AE, PFP, and RE of rice. NIVs had relatively high IE and $\mathrm{PE}$ under the $\mathrm{N} 1$ treatment but showed low $\mathrm{AE}, \mathrm{PFP}$, and RE, indicating that $\mathrm{N}$ absorbed by plants under the $\mathrm{N} 1$ treatment could not be efficiently transported to the grain. 
Table 4. Grain yield and yield components of rice under various N managements.

\begin{tabular}{|c|c|c|c|c|c|c|c|}
\hline Variety $^{1}$ & Treatment $^{2}$ & $\begin{array}{l}\text { Grain Yield } \\
\quad\left(\mathrm{t} \mathrm{ha}^{-1}\right)\end{array}$ & $\begin{array}{l}\text { Panicles } \\
\text { per } \mathrm{m}^{2}\end{array}$ & $\begin{array}{l}\text { Spikelets } \\
\text { per Panicle }\end{array}$ & $\begin{array}{l}\text { Total Spikelets } \\
\qquad\left(\times 10^{3} \mathrm{~m}^{-2}\right)\end{array}$ & $\begin{array}{l}\text { Filled Grain } \\
(\%)\end{array}$ & $\begin{array}{c}\text { Grain Weight } \\
\text { (mg) }\end{array}$ \\
\hline \multirow[t]{4}{*}{ HD-5 } & N0 & $5.7 \mathrm{~d}^{3}$ & $203 \mathrm{~b}$ & 105 ef & $21.3 \mathrm{~g}$ & $93.1 \mathrm{a}$ & $28.6 \mathrm{a}$ \\
\hline & N1 & $9.2 \mathrm{abc}$ & $286 \mathrm{a}$ & $122 \mathrm{~cd}$ & $34.9 \mathrm{de}$ & $92.1 \mathrm{ab}$ & $28.6 \mathrm{a}$ \\
\hline & N2 & $9.4 \mathrm{ab}$ & $288 \mathrm{a}$ & $125 \mathrm{c}$ & $36.0 \mathrm{~cd}$ & $91.7 \mathrm{ab}$ & $28.5 \mathrm{a}$ \\
\hline & N3 & $9.9 \mathrm{a}$ & $287 \mathrm{a}$ & $138 \mathrm{~b}$ & $39.6 \mathrm{a}$ & 89.5 de & $27.9 \mathrm{ab}$ \\
\hline \multirow[t]{4}{*}{ LJ-7 } & N0 & $5.6 \mathrm{~d}$ & $198 \mathrm{~b}$ & $112 \mathrm{de}$ & $22.2 \mathrm{~g}$ & $92.8 \mathrm{a}$ & $27.3 \mathrm{~b}$ \\
\hline & N1 & $9.2 \mathrm{abc}$ & $275 a$ & $133 \mathrm{bc}$ & 36.6 bcd & $92.0 \mathrm{ab}$ & $27.2 \mathrm{~b}$ \\
\hline & N2 & $9.3 \mathrm{ab}$ & $276 \mathrm{a}$ & $136 \mathrm{~b}$ & $37.5 \mathrm{bc}$ & $91.8 \mathrm{ab}$ & $26.9 \mathrm{bc}$ \\
\hline & N3 & $9.8 \mathrm{a}$ & $279 \mathrm{a}$ & $147 \mathrm{a}$ & $41.0 \mathrm{a}$ & $89.4 \mathrm{de}$ & $26.6 c$ \\
\hline \multirow[t]{4}{*}{ ZD-1 } & N0 & $5.2 \mathrm{e}$ & $201 \mathrm{~b}$ & $103 \mathrm{f}$ & $20.7 \mathrm{~g}$ & $91.3 \mathrm{abc}$ & $27.4 \mathrm{~b}$ \\
\hline & N1 & $8.4 \mathrm{c}$ & $289 a$ & 113 de & $32.7 \mathrm{f}$ & $91.4 \mathrm{abc}$ & $28.1 \mathrm{a}$ \\
\hline & N2 & $8.5 \mathrm{bc}$ & $288 a$ & $117 \mathrm{~d}$ & 33.7 ef & $90.3 \mathrm{bcd}$ & $27.8 \mathrm{ab}$ \\
\hline & N3 & $8.6 \mathrm{bc}$ & $284 \mathrm{a}$ & $127 \mathrm{c}$ & $36.1 \mathrm{~cd}$ & $86.8 \mathrm{f}$ & $27.5 \mathrm{~b}$ \\
\hline \multirow[t]{4}{*}{$\mathrm{YJ}-4$} & N0 & $5.1 \mathrm{e}$ & $195 \mathrm{~b}$ & $109 \mathrm{e}$ & $21.3 \mathrm{~g}$ & 89.7 cde & $26.5 c$ \\
\hline & N1 & $8.3 c$ & $284 \mathrm{a}$ & $124 \mathrm{c}$ & $35.2 \mathrm{de}$ & $88.9 \mathrm{de}$ & $26.4 \mathrm{c}$ \\
\hline & N2 & $8.4 c$ & $282 \mathrm{a}$ & $128 \mathrm{c}$ & $36.1 \mathrm{~cd}$ & 88.4 ef & $26.2 \mathrm{c}$ \\
\hline & N3 & $8.6 \mathrm{bc}$ & $281 \mathrm{a}$ & $135 \mathrm{~b}$ & $37.9 \mathrm{~b}$ & $87.1 \mathrm{f}$ & $26.0 \mathrm{c}$ \\
\hline
\end{tabular}

${ }^{1}$ HD-5, Huaidao 5; LJ-7, Lianjing 7; ZD-1, Zhongdao 1; and YJ-4, Yangjing 4038. ${ }^{2}$ N0, zero-N control; N1, panicle N applied at spikelet differentiation (SD); N2, panicle N split at PI and SD; and N3, panicle N applied at panicle initiation (PI). ${ }^{3}$ No shared letter indicates statistical significance at the $p=0.05$ level within the same column.

Table 5. Nitrogen (N) uptake and N-use efficiency (NUE) of rice under various $\mathrm{N}$ managements.

\begin{tabular}{|c|c|c|c|c|c|c|c|}
\hline Variety $^{1}$ & Treatment $^{2}$ & $\begin{array}{l}\text { N Uptake } \\
\left(\mathrm{kg} \mathrm{ha}^{-1}\right)\end{array}$ & $\begin{array}{c}\text { IE } \\
\left(\mathrm{kg} \mathrm{kg}^{-1}\right)\end{array}$ & $\begin{array}{c}\mathrm{AE} \\
\left(\mathrm{kg} \mathrm{kg}^{-1}\right)\end{array}$ & $\begin{array}{c}\text { PFP } \\
\left(\mathrm{kg} \mathrm{kg}^{-1}\right)\end{array}$ & $\begin{array}{l}\text { RE } \\
(\%)\end{array}$ & $\begin{array}{c}\text { PE } \\
\left(\mathrm{kg} \mathrm{kg}^{-1}\right)\end{array}$ \\
\hline \multirow[t]{4}{*}{ HD-5 } & No & $70.2 \mathrm{~d}^{3}$ & 80.9 a & & & & \\
\hline & N1 & 139.8 bc & $65.7 c$ & $17.6 \mathrm{bc}$ & $46.0 \mathrm{c}$ & 34.8 ef & $50.4 \mathrm{ab}$ \\
\hline & N2 & $147.1 \mathrm{ab}$ & $64.0 \mathrm{~cd}$ & $18.7 \mathrm{~b}$ & $47.1 \mathrm{bc}$ & $38.5 \mathrm{~b}$ & $48.5 \mathrm{bcd}$ \\
\hline & N3 & $151.3 \mathrm{a}$ & $65.4 \mathrm{c}$ & $21.1 \mathrm{a}$ & $49.5 \mathrm{a}$ & $40.6 \mathrm{a}$ & $51.9 \mathrm{a}$ \\
\hline \multirow[t]{4}{*}{ LJ-7 } & N0 & $70.3 \mathrm{~d}$ & 79.9 a & & & & \\
\hline & N1 & $142.2 \mathrm{bc}$ & $64.3 \mathrm{~cd}$ & $17.7 \mathrm{bcd}$ & $45.8 \mathrm{c}$ & $36.0 \mathrm{de}$ & $49.1 \mathrm{bc}$ \\
\hline & N2 & $148.4 \mathrm{ab}$ & $62.5 \mathrm{~d}$ & $18.3 \mathrm{bc}$ & $46.4 \mathrm{c}$ & $39.1 \mathrm{~b}$ & $46.7 \mathrm{de}$ \\
\hline & N3 & $153.0 \mathrm{a}$ & $63.7 \mathrm{~cd}$ & $20.7 \mathrm{a}$ & $48.8 \mathrm{ab}$ & $41.4 \mathrm{a}$ & $49.9 \mathrm{abc}$ \\
\hline \multirow[t]{4}{*}{ ZD-1 } & N0 & $67.7 \mathrm{~d}$ & $76.5 \mathrm{~b}$ & & & & \\
\hline & N1 & $134.8 \mathrm{c}$ & $62.2 \mathrm{~d}$ & $16.1 \mathrm{~d}$ & $42.0 \mathrm{~d}$ & $33.6 \mathrm{fg}$ & $47.8 \mathrm{~cd}$ \\
\hline & N2 & $140.8 \mathrm{bc}$ & $60.1 \mathrm{de}$ & $16.4 \mathrm{~d}$ & $42.3 \mathrm{~d}$ & $36.6 \mathrm{~d}$ & $44.9 \mathrm{e}$ \\
\hline & N3 & $144.3 \mathrm{ab}$ & $59.7 \mathrm{e}$ & $17.2 \mathrm{~cd}$ & $43.1 \mathrm{~d}$ & $38.3 \mathrm{bc}$ & $44.8 \mathrm{e}$ \\
\hline \multirow[t]{4}{*}{$\mathrm{YJ}-4$} & N0 & $67.5 \mathrm{~d}$ & $74.8 \mathrm{~b}$ & & & & \\
\hline & N1 & $133.9 \mathrm{c}$ & $61.8 \mathrm{~d}$ & $16.1 \mathrm{~d}$ & $41.4 \mathrm{~d}$ & $33.2 \mathrm{~g}$ & $48.5 \mathrm{bcd}$ \\
\hline & N2 & $140.5 b c$ & $59.5 \mathrm{e}$ & $16.6 \mathrm{~cd}$ & $41.8 \mathrm{~d}$ & $36.5 \mathrm{e}$ & $45.3 \mathrm{e}$ \\
\hline & N3 & $141.6 \mathrm{bc}$ & $60.7 \mathrm{de}$ & $17.7 \mathrm{bc}$ & $43.0 \mathrm{~d}$ & $37.1 \mathrm{~cd}$ & $47.8 \mathrm{~cd}$ \\
\hline
\end{tabular}

${ }^{1}$ HD-5, Huaidao 5; LJ-7, Lianjing 7; ZD-1, Zhongdao 1; and YJ-4, Yangjing 4038. ${ }^{2}$ N0, zero-N control; N1, panicle N applied at spikelet differentiation (SD); N2, panicle N split at PI and SD; and N3, panicle N applied at panicle initiation (PI). ${ }^{3} \mathrm{No}$ shared letter indicates statistical significance at the $p=0.05$ level within the same column.

\subsection{Root Biomass, Root Length, Root Oxidation Activity, and Leaf Photosynthetic Rate}

The root biomass and ROA of each variety at HT were the highest under the N3 treatment, followed by the $\mathrm{N} 2$ and N1 treatments. Under the same N treatment, the root biomass, root length, and ROA of NEVs were significantly higher than those of NIVs (Figure $3 \mathrm{~A}-\mathrm{C})$. The change of photosynthetic rate was consistent with $\mathrm{ROA}\left(\mathrm{R}^{2}=0.93\right.$, $\mathrm{n}=16$ ), indicating an interaction between roots and shoots. 

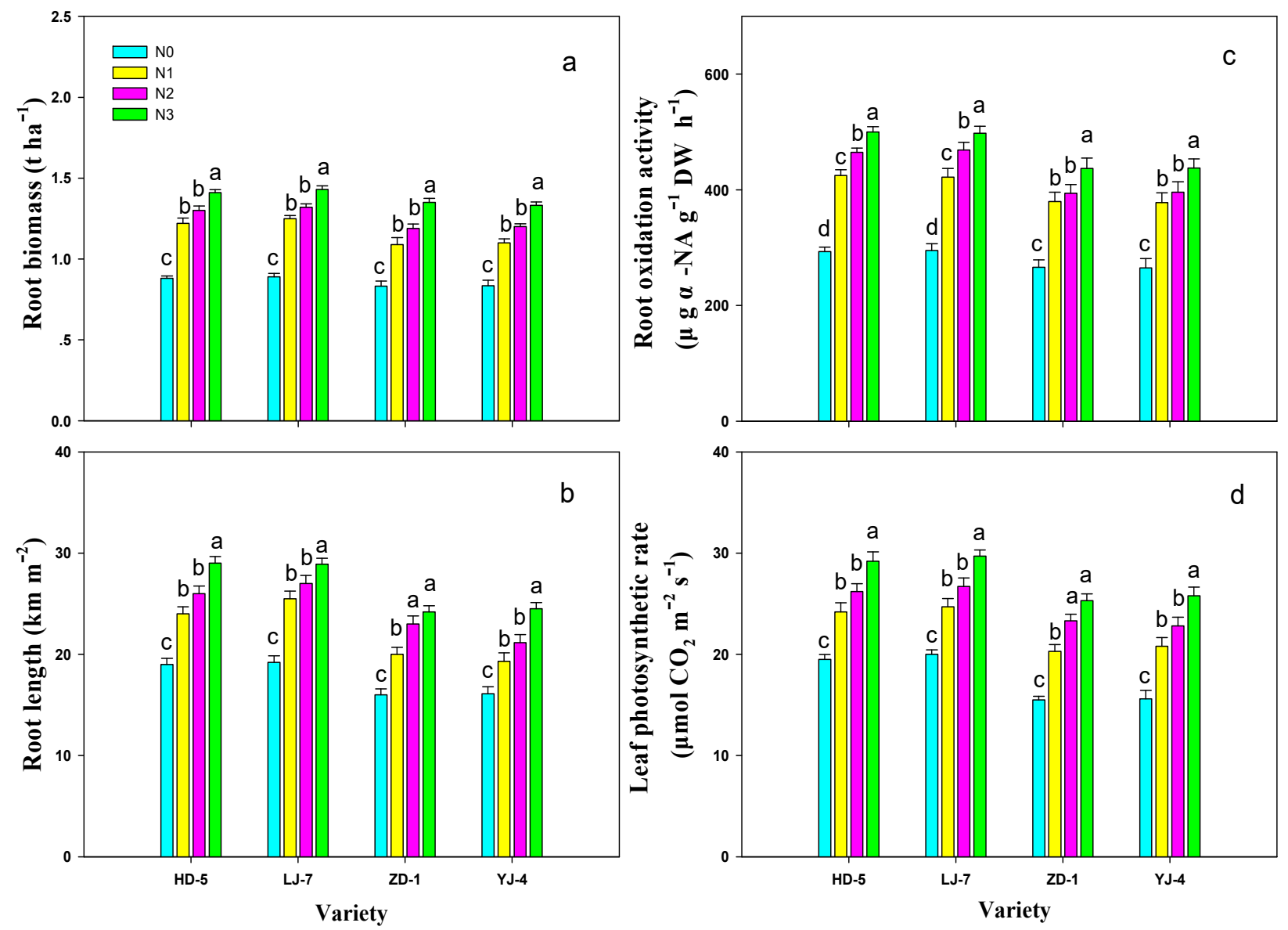

Figure 3. Root biomass (a), root length (b), root oxidation activity (c), and leaf photosynthetic rate (d) of rice at heading under different $\mathrm{N}$ treatment: the vertical bars represent the \pm standard error of the mean $(n=5)$, where these exceed the size of the symbol. No shared letter above the column indicates statistical significance at the $p=0.05$ level within the same variety. N0, zero-N control; N1, panicle N applied at spikelet differentiation (SD); N2, panicle N split at PI and SD; and N3, panicle $\mathrm{N}$ applied at panicle initiation (PI). HD-5, Huaidao 5; LJ-7, Lianjing 7; ZD-1, Zhongdao 1; and YJ-4, Yangjing 4038.

\subsection{LAI and LAD}

From N1 to N3, the LAI gradually increased at HT, and the LAI of N3 was significantly higher than that of N1. At the maturity stage, the difference in LAI for N1, N2, and N3 was not significant (Figure 4). The LADs from PI to HT and from HT to MA under the N3 treatment were significantly higher than those under the N1 and N2 treatments, and the LAI and LAD of NEVs were higher than those of NIVs.

\subsection{Carbon and Nitrogen Remobilization}

At heading, the NSC accumulated by NEVs was significantly higher than that of NIVs under the N0, N2, and N3 treatments, and the difference was not significant under the N1 treatment (Table 6). Between different $\mathrm{N}$ treatments, the NSC at MA was not significantly different, but the NSC levels at HT decreased in the order N3 $>$ N2 $>$ N1. Therefore, the NSC transport rate under N3 was higher than those under N2 and N1. Compared with $\mathrm{N} 1$ and N2, the amount of $\mathrm{N}$ accumulated in the stem and leaf at HT was highest under $\mathrm{N} 3$, and the amount of residual N in MA was lowest in this treatment. Increased fertilizer amount applied at the stage of PI increased the $\mathrm{N}$ transport rate from stems and leaves to grain during the grain filling stage. 

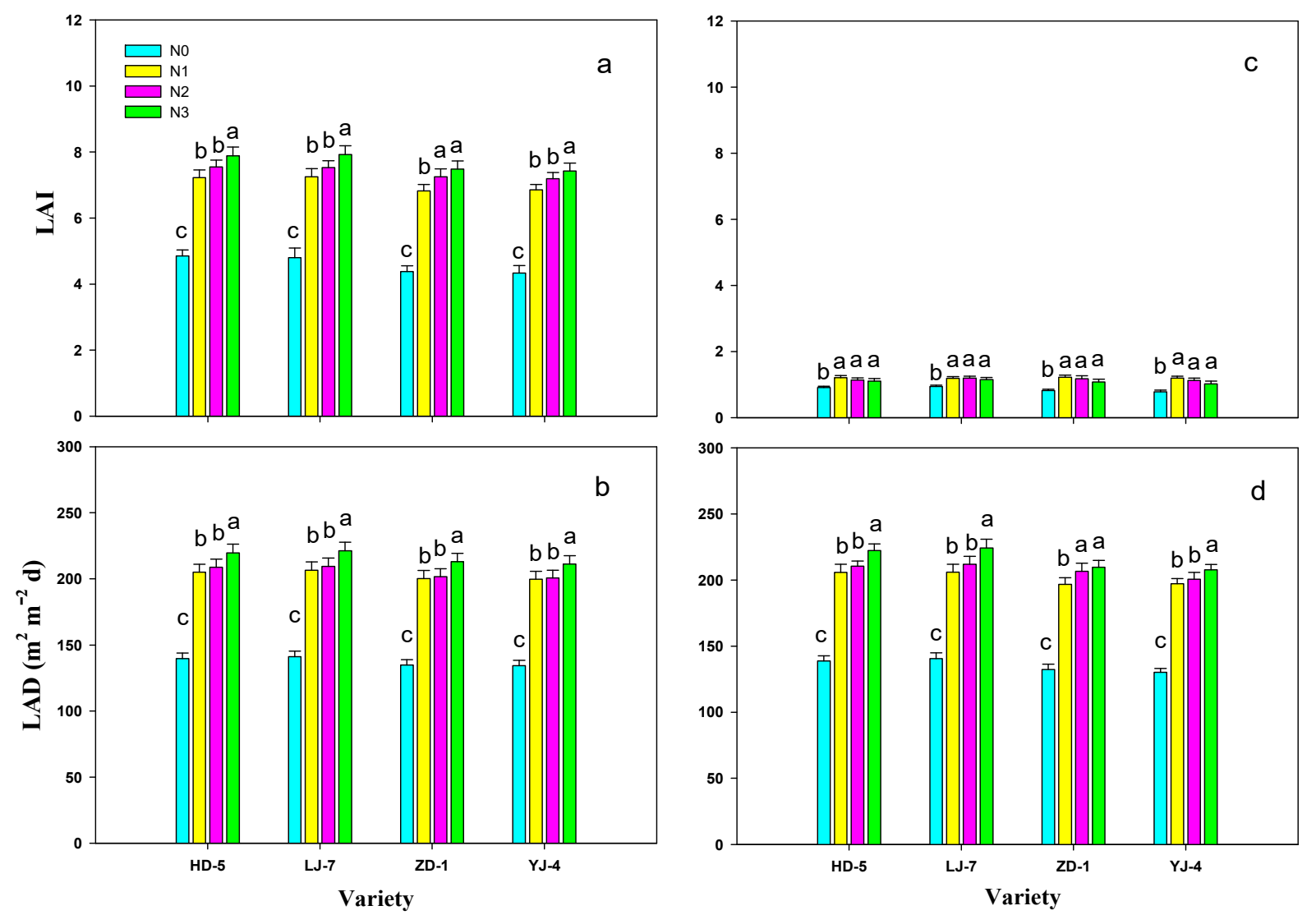

Figure 4. Leaf area index (LAI) of rice at heading time (a) and maturity (c), and Leaf area duration (LAD) from panicle initiation to heading (b) and from heading to maturity $(\mathbf{d})$ under various $\mathrm{N}$ management strategies: the vertical bars represent the \pm standard error of the mean, where these exceed the size of the symbol. No shared letter above the column indicates statistical significance at the $p=0.05$ level within the same variety. N0, zero-N control; N1, panicle N applied at spikelet differentiation (SD); N2, panicle N split at PI and SD; and N3, panicle N applied at panicle initiation (PI). HD-5, Huaidao 5; LJ-7, Lianjing 7; ZD-1, Zhongdao 1; and YJ-4, Yangjing 4038.

Table 6. Nitrogen $(\mathrm{N})$ uptake and NUE of rice under various $\mathrm{N}$ managements.

\begin{tabular}{|c|c|c|c|c|c|c|c|}
\hline Variety $^{1}$ & Treatment ${ }^{2}$ & 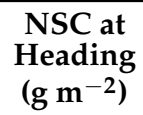 & $\begin{array}{l}\text { NSC at } \\
\text { Maturity } \\
\left(\mathrm{g} \mathrm{m}^{-2}\right)\end{array}$ & $\begin{array}{c}\text { Remobilized } \\
\text { NSC Reserve } \\
\qquad(\%)^{3}\end{array}$ & $\begin{array}{l}\text { N Accumulation } \\
\text { at Heading } \\
\left(\mathrm{kg} \mathrm{ha}^{-1}\right)\end{array}$ & $\begin{array}{l}\text { N Accumulation } \\
\text { at Maturity } \\
\left(\mathrm{kg} \mathrm{ha}^{-1}\right)\end{array}$ & $\begin{array}{l}\text { N Translocation } \\
\text { Rate (\%) }\end{array}$ \\
\hline \multirow[t]{4}{*}{ HD-5 } & No & $159 d^{5}$ & $58 \mathrm{~b}$ & $63.3 \mathrm{a}$ & $63 \mathrm{~d}$ & $22 \mathrm{~d}$ & $65.1 \mathrm{a}$ \\
\hline & N1 & $267 c$ & $148 \mathrm{a}$ & $44.6 \mathrm{~g}$ & $137 \mathrm{bc}$ & $65 \mathrm{a}$ & $52.4 \mathrm{de}$ \\
\hline & N2 & $298 \mathrm{ab}$ & $144 \mathrm{a}$ & $51.7 \mathrm{~d}$ & $142 \mathrm{ab}$ & $62 \mathrm{ab}$ & $56.3 \mathrm{c}$ \\
\hline & N3 & $303 \mathrm{ab}$ & $144 \mathrm{a}$ & $52.5 \mathrm{~d}$ & $150 \mathrm{a}$ & $55 \mathrm{c}$ & $63.3 \mathrm{ab}$ \\
\hline \multirow[t]{4}{*}{ LJ-7 } & N0 & $162 \mathrm{~d}$ & $59 \mathrm{~b}$ & $63.8 \mathrm{a}$ & $59 \mathrm{~d}$ & $21 \mathrm{~d}$ & $64.1 \mathrm{ab}$ \\
\hline & N1 & $265 c$ & 148 a & $44.2 \mathrm{~g}$ & $136 \mathrm{bc}$ & $64 a b$ & 53.5 cde \\
\hline & N2 & $302 \mathrm{ab}$ & $147 \mathrm{a}$ & $51.3 \mathrm{~d}$ & $140 \mathrm{ab}$ & $63 a b$ & $55.2 \mathrm{~cd}$ \\
\hline & N3 & $311 \mathrm{a}$ & $143 \mathrm{a}$ & $54.0 \mathrm{c}$ & $150 \mathrm{a}$ & $56 c$ & $63.0 \mathrm{ab}$ \\
\hline \multirow[t]{4}{*}{ ZD-1 } & N0 & $143 \mathrm{~d}$ & $61 \mathrm{~b}$ & $57.5 \mathrm{~b}$ & $56 \mathrm{~d}$ & $22 \mathrm{~d}$ & $61.6 \mathrm{~b}$ \\
\hline & N1 & $265 c$ & 149 a & $43.8 \mathrm{~g}$ & $123 \mathrm{c}$ & $63 \mathrm{ab}$ & $48.9 \mathrm{f}$ \\
\hline & N2 & $268 c$ & $141 \mathrm{a}$ & $47.4 \mathrm{f}$ & $126 \mathrm{c}$ & $62 \mathrm{ab}$ & $50.8 \mathrm{ef}$ \\
\hline & N3 & $283 \mathrm{bc}$ & $145 \mathrm{a}$ & $48.8 \mathrm{ef}$ & $130 \mathrm{bc}$ & $57 \mathrm{c}$ & $56.4 \mathrm{c}$ \\
\hline \multirow[t]{4}{*}{$\mathrm{YJ}-4$} & N0 & $146 \mathrm{~d}$ & $62 \mathrm{~b}$ & $57.8 \mathrm{~b}$ & $55 \mathrm{~d}$ & $22 \mathrm{~d}$ & $61.9 \mathrm{~b}$ \\
\hline & N1 & $264 \mathrm{c}$ & $146 \mathrm{a}$ & $44.7 \mathrm{~g}$ & 124 c & $64 \mathrm{ab}$ & $48.5 \mathrm{f}$ \\
\hline & N2 & 272 c & $142 \mathrm{a}$ & $47.8 \mathrm{ef}$ & $129 \mathrm{bc}$ & $62 \mathrm{~b}$ & $52.5 \mathrm{de}$ \\
\hline & N3 & $287 \mathrm{abc}$ & $144 \mathrm{a}$ & $49.8 \mathrm{e}$ & $130 \mathrm{bc}$ & $58 c$ & $56.0 \mathrm{c}$ \\
\hline
\end{tabular}

${ }^{1}$ HD-5, Huaidao 5; LJ-7, Lianjing 7; ZD-1, Zhongdao 1; and YJ-4, Yangjing 4038. ${ }^{2}$ N0, zero-N control; N1, panicle N applied at spikelet differentiation (SD); N2, panicle N split at PI and SD; and N3, panicle N applied at panicle initiation (PI). ${ }^{3}$ (NSC accumulation in stems at heading - NSC accumulation in stems at maturity)/NSC accumulation in stems at heading $\times 100 .{ }^{4}$ (N accumulation in stems and leaves at heading $-\mathrm{N}$ accumulation in stems and leaves at maturity)/ $\mathrm{N}$ accumulation in stems and leaves at heading $\times 100 .{ }^{5} \mathrm{No}$ shared letter indicates statistical significance at the $p=0.05$ level within the same column. 


\section{Discussion}

Nitrogen management is a key step in improving the NUE of rice fields, and it is of great importance in rice production and environmental protection $[23,24]$. In this study, we observed that, at a moderate $\mathrm{N}$ rate, a higher amount of $\mathrm{N}$ applied at PI led to higher yield and NUE of NEVs, and it was not necessary to apply further $\mathrm{N}$ fertilizer at the spikelet differentiation stage. The results showed that improving $\mathrm{N}$ management at a moderate $\mathrm{N}$ rate could achieve both high yield and high efficiency. After the $\mathrm{N}$ applied at PI was increased, the yield and NUE increases were more significant for NEVs (Tables 4 and 5). We observed that NEV had better root and shoot traits than NIV at the N rates in this study (Figures 3 and 4). However, we also found that there was no significant difference between NEV and NIV at the $\mathrm{N}$ rate of $300 \mathrm{~kg} \mathrm{ha}^{-1}$ [15]. This suggests that NEVs could play a better role under moderate or low $\mathrm{N}$ rates. The response of NEVs was asymptotic, with a maximum value already reached at about $260 \mathrm{~kg} \mathrm{ha}^{-1}$, whereas the NIVs still showed a strong response to $\mathrm{N}$ above $300 \mathrm{~kg} \mathrm{ha}^{-1}$.

Increasing the number of spikelets per unit area is the key to improving yield and NUE [25]. Therefore, the increased application of N fertilizer at PI is recommended to increase the total number of spikelets in rice production [26,27]. This may be more effective at moderate and low $\mathrm{N}$ rates. In this study, the total number of spikelets under the N3 treatment was significantly higher than that under N2 (Table 4). However, when the $\mathrm{N}$ rate was further increased, increasing the proportion of $\mathrm{N}$ applied at PI could not considerably increase the number of spikelets [28]. This may be because of the source and sink relationship of rice changes at the high $\mathrm{N}$ rate. At high $\mathrm{N}$ rates, the delay of $\mathrm{N}$-fertilizer application could improve the grain filling efficiency, and this effect was greater on large-spike varieties than on small-spike varieties $[18,23]$. At high $\mathrm{N}$ rates, although the proportion of $\mathrm{N}$ fertilizer in the early stage was reduced, the amount of $\mathrm{N}$ fertilizer applied after reduction remained higher than the amount of $\mathrm{N}$ fertilizer applied in the early stage of the moderate $\mathrm{N}$ treatment.

NEVs are mostly multi-spike varieties, and green super rice is also mostly multi-spike types [19]. This may be because multi-spike varieties are more suitable for mechanical operations and have a relatively low requirement for $\mathrm{N}$ input [29]. Under the conditions of mechanized and simplified cultivation, the growth period of rice has shortened and the number of spikelets per panicle has been reduced; thus, the advantages of large-spike varieties have weakened [29]. Therefore, multi-spike varieties are more suitable for light and simplified cultivation. Although large-spike cultivars have relatively high biomass and photosynthetic characteristics, the number of spikelets per panicle is large and the quantity of assimilates distributed to each grain is lower than for multi-spike varieties [30]. As a result, higher $\mathrm{N}$-fertilizer input is required, and the late stage with unstable grain filling percentage requires more labor input.

Root morphology and physiology play very important roles in nutrient absorption and growth of the aboveground parts in plants [31]. The earlier the $\mathrm{N}$ application period, the greater the promotion effect on the root system [32]. In this study, with an increasing amount of applied $\mathrm{N}$ fertilizer from N1 to N3, root biomass, root length, and ROA gradually increased, which is consistent with previous studies (Figure 3). Moreover, Dong et al. proposed that an increase in the number of spikelets will help improve the root characteristics of the plant and the ability to absorb N [31]. The improvement of root characteristics is also conducive to the photosynthetic characteristics of the aboveground parts [20]. In the current study, under the N3 treatment, the LAI and photosynthesis at the heading stage of the aboveground part were significantly improved (Figure 4). LAI is a basic indicator for evaluating the coordination between sources and sinks and for balancing the development of the aboveground and underground parts [33]. The LAI results showed that an improvement in root and canopy functions after increasing the amount of $\mathrm{N}$ applied at PI supported increases in yield and NUE. This is likely to be related to increases in source quantity (LAI and LAD) and source quality (ROA and photosynthesis) and to an increase in the sink capacity (total spikelets). 
Some researchers have proposed that increasing the accumulation of NSC in the stem before the heading stage can increase the grain filling efficiency [34]. Fu et al. showed that NSC is significantly positively correlated with sink strength [35]. At the heading stage, the NSC content in stems under the N3 treatment was significantly higher than those under the N1 and N2 treatments and that the NSC transport efficiency was also improved (Table 6). $\mathrm{C}$ and $\mathrm{N}$ metabolism during grain filling is a coupled process [36]. After the $\mathrm{N}$ fertilizer is applied at PI, the $\mathrm{N}$ transport efficiency is also improved. The increase in the $\mathrm{C}$ and $\mathrm{N}$ transport rates is an important physiological reason for the increases in grain filling efficiency and rice yield. In summary, increasing the proportion of $\mathrm{N}$ fertilizer applied at PI can increase the source, expand the sink, and strengthen the flow at a moderate $\mathrm{N}$ rate.

\section{Conclusions}

Increasing the proportion of $\mathrm{N}$ applied at PI under a moderate $\mathrm{N}$ rate could not only increase the NEV yield but also increase NUE. Under the N3 treatment, there were increases in root biomass and root length, LAI and LAD, photosynthesis and ROA, and C and $\mathrm{N}$ transport, which may help achieve the dual goal of increasing yield and efficiency. Improved root and canopy functions and a more coordinated source and sink relationship will help increase yield and NUE. We suggest that increasing the amount of $\mathrm{N}$ fertilizer applied at PI is an effective method to reduce NEV yield loss and to increase NUE when the amount of applied $\mathrm{N}$ is reduced below the optimal $\mathrm{N}$ rate.

Author Contributions: Methodology, T.L.; validation, T.L. and C.S.; formal analysis, C.J.; investigation, C.J.; resources, C.S.; data curation, C.J.; writing—original draft preparation, C.J.; writing—review and editing, C.J.; visualization, T.L.; supervision, T.L.; project administration, C.S.; funding acquisition, C.S. All authors have read and agreed to the published version of the manuscript.

Funding: This research was funded by the National Natural Science Foundation of China (32001465, 31872852, and 31701355), by the National Key Research and Development Program of China (2018YFD0300805), and by the Priority Academic Program Development of Jiangsu Higher Education Institutions.

Acknowledgments: We thank the editors and three anonymous reviewers for their constructive comments.

Conflicts of Interest: The authors declare no conflict of interest.

\section{References}

1. Peng, S.; Buresh, R.J.; Huang, J.; Zhong, X.; Zou, Y.; Yang, J.; Wang, G.; Liu, Y.; Hu, R.; Tang, Q.; et al. Improving nitrogen fertilization in rice by site-specific N management: A review. Agron. Sustain. Dev. 2010, 30, 649-656. [CrossRef]

2. Liu, X.; Zhang, Y.; Han, W.; Tang, A.; Shen, J.; Cui, Z.; Vitousek, P.; Erisman, J.W.; Goulding, K.; Christie, P.; et al. Enhanced nitrogen deposition over China. Nature 2013, 494, 459-462. [CrossRef]

3. Zhu, Z.; Jin, J. Fertilizer use and food security in China. Plant Nutr. Fert. Sci. 2013, 19, 259-273.

4. Li, H.; Hu, B.; Chu, C. Nitrogen use efficiency in crops: Lessons from Arabidopsis and rice. J. Exp. Bot. 2017, 68, 2477-2488. [CrossRef] [PubMed]

5. Fan, M.; Shen, J.; Yuan, L.; Jiang, R.; Chen, X.; Davies, W.J.; Zhang, F. Improving crop productivity and resource use efficiency to ensure food security and environmental quality in China. J. Exp. Bot. 2012, 63, 13-24. [CrossRef] [PubMed]

6. Huang, L.; Sun, F.; Yuan, S.; Peng, S.; Wang, F. Different mechanisms underlying the yield advantage of ordinary hybrid and super hybrid rice over inbred rice under low and moderate N input conditions. Field Crop. Res. 2018, 216, 150-157. [CrossRef]

7. National Bureau of Statistics of China. Available online: http:/ / data.stats.gov.cn (accessed on 1 July 2020).

8. Liu, L.; Wang, K.; Bian, J.; Xiong, Y.; Chen, L.; Wang, Z.; Yang, J. Differences in yield response to nitrogen fertilizer among rice cultivars and their relationship with root morphology and physiology. Acta Agron. Sin. 2014, 40, 1999-2007. [CrossRef]

9. Li, Y.; Chen, C.; Tang, X.; Ji, X. Determination of optimum nitrogen application rates in Zhejiang Province, China, based on rice yields and ecological security. J. Integr. Agric. 2015, 14, 2426-2433. [CrossRef]

10. Chen, X.; Cui, Z.; Fan, M.; Vitousek, P.; Zhao, M.; Ma, W.; Wang, Z.; Zhang, W.; Yan, X.; Yang, J.; et al. Producing more grain with lower environmental costs. Nature 2014, 514, 486-491. [CrossRef] [PubMed]

11. Li, P.; Chen, F.; Cai, H.; Liu, J.; Pan, Q.; Liu, Z.; Gu, R.; Mi, G.; Zhang, F.; Yuan, L. A genetic relationship between nitrogen use efficiency and seedling root traits in maize as revealed by QTL analysis. J. Exp. Bot. 2015, 66, 3175-3188. [CrossRef]

12. Guo, J.; Liu, X.; Zhang, Y.; Shen, J.; Han, W.; Zhang, W.; Christie, P.; Goulding, K.; Vitousek, P.M.; Zhang, F. Significant acidification in major Chinese croplands. Science 2010, 327, 1008-1010. [CrossRef] [PubMed] 
13. Kant, S.; Bi, Y.M.; Rothstein, S.J. Understanding plant response to nitrogen limitation for the improvement of crop nitrogen use efficiency. J. Exp. Bot. 2011, 62, 1490-1509. [CrossRef] [PubMed]

14. Hussain, S.; Peng, S.; Fahad, S.; Khaliq, A.; Huang, J.; Cui, K.; Nie, L. Rice management interventions to mitigate greenhouse gas emissions: A review. Environ. Sci. Pollut. Res. 2015, 22, 3342-3360. [CrossRef] [PubMed]

15. Ju, C.; Buresh, R.J.; Wang, Z.; Zhang, H.; Liu, L.; Yang, J.; Zhang, J. Root and shoot traits for rice varieties with higher grain yield and higher nitrogen use efficiency at lower nitrogen rates application. Field Crop. Res. 2015, 175, 47-55. [CrossRef]

16. Li, M.; Zhang, H.; Yang, X.; Ge, M.; Ma, Q.; Wei, H.; Dai, Q.; Huo, Z.; Xu, K.; Luo, D. Accumulation and utilization of nitrogen, phosphorus and potassium of irrigated rice cultivars with high productivities and high $\mathrm{N}$ use efficiencies. Field Crop. Res. 2014, 161, 55-63. [CrossRef]

17. Ju, C. Agronomic and Physiological Traits for Rice Cultivars Differing in Response to Nitrogen. Ph.D. Thesis, Yangzhou University, Yangzhou, China, 2017.

18. Zhang, Z.; Chu, G.; Liu, L.; Wang, Z.; Wang, X.; Zhang, H.; Yang, J.; Zhang, J. Mid-season nitrogen application strategies for rice varieties differing in panicle size. Field Crop. Res. 2013, 150, 9-18. [CrossRef]

19. Peng, S. Reflection on China's rice production strategies during the transition period. Sci. Sin. Vitae 2014, 44, 845-850. [CrossRef]

20. Counce, P.A.; Keisling, T.C.; Mitchell, A.J. A uniform, objective, and adaptive system for expressing rice development. Crop Sci. 2000, 40, 436-443. [CrossRef]

21. Chu, G.; Chen, T.; Wang, Z.; Yang, J.; Zhang, J. Morphological and physiological traits of roots and their relationships with water productivity in water-saving and drought-resistant rice. Field Crop. Res. 2014, 162, 108-119. [CrossRef]

22. Yoshida, S.; Forno, D.; Cock, J.; Gomez, K. Laboratory Manual for Physiological Studies of Rice; International Rice Research Institute: Manila, Philippines, 1976; pp. 24-79.

23. Xue, Y.; Duan, H.; Liu, L.; Wang, Z.; Yang, J.; Zhang, J. An improved crop management increases grain yield and nitrogen and water use efficiency in rice. Crop Sci. 2013, 53, 271-284. [CrossRef]

24. Liu, L.; Chen, T.; Wang, Z.; Zhang, H.; Yang, J.; Zhang, J. Combination of site-specific nitrogen management and alternate wetting and drying irrigation increases grain yield and nitrogen and water use efficiency in super rice. Field Crop. Res. 2013, 154, 226-235. [CrossRef]

25. Kamiji, Y.; Yoshida, H.; Palta, J.A.; Sakuratani, T.; Shiraiwa, T. N applications that increase plant N during panicle development are highly effective in increasing spikelet number in rice. Field Crop. Res. 2011, 122, 242-247. [CrossRef]

26. Ghaley, B.B. Uptake and utilization of 5-split nitrogen topdressing in an improved and a traditional rice cultivar in the Bhutan Highlands. Exp. Agric. 2012, 48, 536-550. [CrossRef]

27. Rehman, H.U.; Basra, S.M.A.; Wahid, A. Optimizing nitrogen-split application time to improve dry matter accumulation and yield in dry direct seeded rice. Int. J. Agric. Biol. 2013, 15, 41-47.

28. Fu, P.; Wang, J.; Zhang, T.; Huang, J.; Peng, S. High nitrogen input causes poor grain filling of spikelets at the panicle base of super hybrid rice. Field Crop. Res. 2019, 244, 107635. [CrossRef]

29. Zhang, H.; Zhang, J.; Gong, J.; Chang, Y.; Li, M.; Gao, H.; Dai, Q.; Huo, Z.; Xu, K.; Wei, H. The productive advantages and formation mechanisms of indica rice to japonica rice. Sci. Agric. Sin. 2013, 46, 686-704.

30. Yang, J.; Zhang, J. Grain-filling problem in 'super' rice. J. Exp. Bot. 2010, 61, 1-4. [CrossRef]

31. Yang, J.; Zhang, H.; Zhang, J. Root morphology and physiology in relation to the yield formation of rice. J. Integr. Agric. 2012, 11, 920-926. [CrossRef]

32. Dong, G.; Chen, C.; Yuan, Q.; Yang, B.; Zhu, Z.; Cao, W.; Zhong, J.; Zhou, J.; Luo, G.; Wang, Y.; et al. The effect of nitrogen fertilizer treatments on root traits and nitrogen use efficiency in indica rice varieties with high nitrogen absorption efficiency. Acta Ecol. Sin. 2016, 36, 642-651.

33. Ling, Q. The Quality of Crop Population; Shanghai Scientific \& Technical Publishers: Shanghai, China, $2005 ;$ pp. 58-63.

34. Katsura, K.; Maeda, S.; Horie, T.; Shiraiwa, T. Analysis of yield attributes and crop physiological traits of Liangyoupeijiu, a hybrid rice recently bred in China. Field Crop. Res. 2007, 103, 170-177. [CrossRef]

35. Fu, J.; Huang, Z.; Wang, Z.; Yang, J.; Zhang, J. Pre-anthesis non-structural carbohydrate reserve in the stem enhances the sink strength of inferior spikelets during grain filling of rice. Field Crop. Res. 2011, 123, 170-182. [CrossRef]

36. Wang, W. Soil Drying in Regulation to the Remobilization of Carbon and Nitrogen Reserves during Grain-Filling Period of Wheat and Rice and Its Physiological Mechanism. Ph.D. Thesis, Yangzhou University, Yangzhou, China, 2003. 